\title{
Model Development of Digital Based Volleyball under Service Skills Instruments
}

\author{
Muslimin $^{1, *}$, Moch. Asmawi ${ }^{1}$, Samsudin ${ }^{1}$, Firmansyah Dlish ${ }^{1}$, James Tangkudung ${ }^{1}$, \\ Aprizal Fikri', Destriana ${ }^{2}$

\begin{abstract}
${ }^{1}$ Program of Sports Education Study, Faculty of Teacher Training and Education, Universitas Bina Darma, Palembang, Indonesia ${ }^{2}$ Physical Education and Health Study Program, Faculty of Teacher Training and Education, Universitas Sriwijaya, Palembang, Indonesia
\end{abstract}

Received September 22, 2020; Revised November 19, 2020; Accepted December 22, 2020

\section{Cite This Paper in the following Citation Styles}

(a): [1] Muslimin, Moch. Asmawi, Samsudin, Firmansyah Dlish, James Tangkudung, Aprizal Fikri, Destriana, "Model Development of Digital Based Volleyball under Service Skills Instruments, "International Journal of Human Movement and Sports Sciences, Vol. 8, No. 6A, pp. 42-46, 2020. DOI: 10.13189/saj.2020.080707.

(b): Muslimin, Moch. Asmawi, Samsudin, Firmansyah Dlish, James Tangkudung, Aprizal Fikri, Destriana (2020). Model Development of Digital Based Volleyball under Service Skills Instruments. International Journal of Human Movement and Sports Sciences, 8(6A), 42-46. DOI: 10.13189/saj.2020.080707.

Copyright $\mathrm{C} 2020$ by authors, all rights reserved. Authors agree that this article remains permanently open access under the terms of the Creative Commons Attribution License 4.0 International License

\begin{abstract}
The purpose of this research is to develop a digital-based volleyball service skills test instrument. The research method used is research and development which adopts Borg and Gall theory which has 10 stages of development. The research subjects numbered 28 male. The results of this development research are the 12 subject small-scale trials getting an average value of $82 \%$ the category of "Good / feasible" to proceed to the large-scale trial phase volleyball players and daughter. Data collection uses observation, questionnaire, interview and test. The results of 16 subject large-scale group trials obtained an average value of $85.3 \%$ in the category of "Good / decent" which means that the digital-based volleyball under service skills test instrument was "feasible" to proceed to the stage of tool implementation. The conclusion from the results of the development of a digital-based volleyball under service skill game instrument "Eligible" is used as a tool to measure the technical ability of volleyball players.
\end{abstract}

Keywords Instrument Model, Under Service Skill, Volleyball, Digital

\section{Introduction}

Coaching sports in a planned, tiered, and sustainable manner through competition to achieve achievement with the support of science and technology (Science and
Technology), science and technology will continue to grow and be utilized for the world of sports, because current technological advances are very beneficial for improving sports achievements. According to research results, Sports video research is a popular topic that has been applied to many prominent sports for a large spectrum of applications [1]. Therefore, Sports video research is a popular topic that has been applied to many prominent sports for a large spectrum of applications [2]. In this paper, we introduce a technology platform which has been developed for the tennis context, able to extract action sequences and provide support to coaches for players' performance analysis during training and official matches

Meanwhile, according to the results of research "The purpose of player tracking technology is to find out the extent of the movements made by players, mark players, and find out how players look" [3]. In line with research according to research with the results of research that most sports can use sensors or other devices to monitor players while other equipment is not possible [4].

From the results of the research above, it shows that science and technology and sports today should go hand in hand, because the development of sports science and technology in developed countries is already very good and the results must also be very good for improving sports achievements. Because, in addition to being supported by good human resources, of course, to carry 
out the development of sports development programs, it is necessary to have good facilities and infrastructure support, one of which is technology-based training and training infrastructure.

Sports coaching can be done either through sports cloub or at school or formal education. According, for junior high school students, students want new skills and develop a mind to learn fair play, good sportsmanship and want to use free time. One game that can be done in stages is a volleyball game. According to how many results of research and expert opinion, according said "The volleyball game contains a series of individual technical-tactical actions that interact during the course of the game" [5]. According Volleyball is a loving and exciting sport, but its poor promotion leads to a low number of consumers, especially in areas where this sport has no tradition [6]. There are several types of basic techniques in volleyball games: service, passing, smesh and block. The basic technique of volleyball according to the results of the study states that "Volleyball is a complex sport where the results in the game depend on cooperation with each player who occupies a position in accordance with the rules of the game [7]. Performance in volleyball games really requires a good psychomotor aspect and is trained on every player. The ability to adapt in a team and physical and psychological abilities influence the outcome of the game " according states "in a process of learning sports teams specifically in volleyball, basically using a tutorial that has a theoretical basis in a cognitive approach that covers the development of strength and skills [8].

Based on the results of this research and several theories, volleyball is done by two opposing teams and tries to generate numbers by turning off the ball in the opponent's area, of course, supported by good physical conditions and good techniques to achieve achievements. However, based on the results of the field survey, volleyball players at the University of Bina Darma are still underperforming, which is caused by several problems among the evaluation tools that are still based on manuals, so that coaches are less objective and find difficult to evaluate the technical abilities of each player. Evaluation techniques that are still lacking in objective are the upper and lower serve volleyball service.

Previous research on the development of volleyball service test instruments conducted with the title Testing Protocol for Monitoring Spike and Serve Speed in Volleyball. The results of the research are two types of test instrument development namely an instrument to see the strength of a smash and an instrument for under service. According to the results of the development research that, to evaluate the results of service techniques can be done using radar-based test instruments [9]. According the model is an imitation, a simulation of a reality composed of specific elements of a number of phenomena that can be investigated by a person and this is an isomorphs of an image obtained abstractly that is a process mentality making generalizations from real examples (the same as describing the atmosphere of the match) [10]. Widiastuti states that tests are tools or instruments used to obtain information about a person or object [11]. To get good measurement results, you should use a test tool or instrument that refers to the purpose of the test itself.

Based on these results there are still weaknesses in terms of components and objectives of the rules of service techniques that make instruments better and in accordance with the rules of volleyball games. Volleyball is not only seen from the speed of the rolling ball because not all techniques are influenced by the speed of the ball. Because with the accuracy of the service ball, right in doing passing and smashes will certainly make the game more leverage in producing points. Therefore the researcher will develop a technical instrument for digital volleyball game service skills. From the results of this development, the components used will be better, digitally based, android application systems, and of course priority to the precision of the bullae measured by using a sensor. Of course the volleyball game service skill test instrument is more effective and efficient compared to the instrument in the previous research.

\section{Material Method}

The research approach used in this research is the research and development of Research and Development (R\&D), which are as follows: 1) Research and information collecting, 2) Planning, 3) Develop preminary form of product, 4) Preliminary field testing, 5) Main product revision, 6) Main field esting, 7) Operational product revision, 8) Operational field testing, 9) Final product revision, and 10) Dissemination and implementation [12].

\subsection{Research Subject}

The research subjects were 28 male at Bina Darma University. Purposive sample technique was chosen in the research of research subjects.

$$
\text { Rumus }=\frac{\mathrm{SH}}{\mathrm{SK}} \times 100 \%
$$

Information:

SH : Calculate Score

SK : Criteria Score or Score Ideal

\subsection{Data Collection Techniques and Instruments}

Data collection techniques in this study (1) observations of spaciousness where the research subjects were carried out, (2) interviews with trainers. Data collection instruments used a questionnaire and volleyball skills tests. Questionnaire can be a closed / open question / statement. According to Sugiyono (2012) the types of questionnaires 
according to their shape are divided into three, viz. (1) Multiple choice questionnaire, (2) Check list. (3) Rating scale

\subsection{Data Analysis Technique}

Data analysis includes all the activities of clarifying, analyzing, using and drawing conclusions from all data collected in action. Whereas quantitative data were obtained by giving a score on a qualitative based on a Likert scale that was converted to a scale value of 4 .

Table 1. Skala Likert

\begin{tabular}{|c|c|}
\hline Skala & Information \\
\hline 1 & Very Inadequate / Good / Suitable \\
\hline 2 & Not Decent / Good / Suitable \\
\hline 3 & Decent / Good / Suitable \\
\hline 4 & Very decent / good / appropriate \\
\hline
\end{tabular}

Percentage is intended to find out the status of something that is presented and presented as a percentage. The formula for calculating eligibility according is as follows [13].

The results of subsequent data calculations are made in the form of a percentage multiplied by $100 \%$ and in the four categories of eligibility by using the Scale as follows. Percentage of Eligibility Category [14].

Table 2. Percentage of Eligibility

\begin{tabular}{|c|c|}
\hline Score as a percentage & Eligibility Category \\
\hline$<40 \%$ & Not Good / Not Eligible \\
\hline $40 \%-55 \%$ & Poor / Inadequate \\
\hline $56 \%-75 \%$ & Good enough / decent enough \\
\hline $76 \%-100 \%$ & Good / Decent \\
\hline
\end{tabular}

Note: (1): Strongly disagree / very improper, (2): Not appropriate / not feasible, (3): Appropriate / feasible, (4): Very appropriate / very feasible.

\section{Result / Findings}

A small group trial was conducted on 12 Universitas Bina Darma volleyball players. The test subjects performed all digital-based volleyball skill testing tests.

Based on the results of a small trial in the diagram above, in the aspect of originality the digital-based volleyball under service skill test instrument scores $82.2 \%$ in the "Good" category means that the digital-based volleyball service skill test instrument is "feasible. The excellence aspect of digital based volleyball under service skills test instrument score $84,3 \%$ in the category of "Good" means that the digital based volleyball under service skills test instrument is "feasible". The aspect of the use of digital based volleyball under service skills test instrument scores $81 \%$ in the "Good" category means that the digital based volleyball under service skills test instrument is "feasible". The safety aspect of digital based volleyball service skill test instrument scores $82.3 \%$ in the "Good" category means that the digital based volleyball under service skill test instrument is "feasible". The excellence aspect of digital-based volleyball under service skills test instrument scores $80,1 \%$ in the category of "Good" means that the digital-based volleyball under service skills test instrument is "feasible". So the average value of the results of small-scale trials is $82 \%$ in the "Good" category which means that the digital-based volleyball under service skills test instrument is "feasible". Large group trials were conducted on 12 male and female volleyball players at Bina Darma University.

Based on the results of large-scale group trials in the diagram above that in the aspect of originality the digital-based volleyball under service skills test instrument scores $85,5 \%$ in the "Good" category means that the digital-based volleyball under service skills test instrument is "feasible". The excellence aspect of the digital-based volleyball under service skills test instrument scores $86 \%$ in the "Good" category means that the digital-based volleyball under service skills test instrument is "feasible". The aspect of the utilization of digital based volleyball service skills test instrument scores $84,5 \%$ in the category of "Good" means that the digital based volleyball skills test instrument is "feasible" The safety aspect of the digital based volleyball under service skills test instrument scores $85 \%$ in the "Good" category "Means that digital volleyball under service skill testing instruments are" feasible ". The excellence aspect of digital-based volleyball skills test instrument score $85,4 \%$ in the category of "Good" means that the digital-based volleyball under service skills test instrument is "feasible". So the average value of the results of large-scale group trials is $85,3 \%$ the category of "Good" which means that the digital-based volleyball skills test instrument is "feasible". Large-scale group trials were conducted on 16 male and female volleyball players at Bina Darma University.

\section{Discussion}

This developmental research aims to provide a new alternative in evaluating the service skills of volleyball game techniques that are more, varied and effective. The product developed is a digital-based volleyball under service skills test kit, where researchers utilize digital technology as the main component to make this test kit. The technology used is the latest development both in software and hardware, so as to produce a good and appropriate product used to measure volleyball service skills. Furthermore for volleyball service tests, previous studies only looked at how fast the smash shots were carried out by volleyball players, using camera radar as a detector, in contrast to the development carried out in this 
study [15]. Development research conducted by Insook Kim and Bomna Ko the conclusion that, in the world of education there is also a need for development between $\mathrm{K}-12$. Thus, development research is very effective to be used as a research method [16]. This research makes smas test kits with the aim of being applicable with volleyball games of the same size where players service exactly at the time of the game. Therefore, the test equipment is made in accordance with the area of half the volleyball court where the test equipment is placed then given numbers as a target. The research with the title "Development of android-based learning media in the form of digital pocket books for basic competency accounting subjects makes an overview of the accounting cycle of service companies in class XI MAN 1 Yogyakarta 2014/2015 academic year" Yogyakarta State University. This research develops an Android-based pocket book learning model. Based on several different elements both in terms of physical / component and software aspects, of course the research on the development of volleyball service skills test is a new innovation and of course the original has not been done by other researchers [17].

In addition, this product will be very helpful in carrying out volleyball service skills tests for beginner athletes as well as students and the general public.

This product has utilized digital technology so that very new and more objective data are generated. Thus the data cannot be changed by athletes so as to minimize data manipulation actions. Obviously with an objective result the coach or teacher will know the actual service skill level of each athlete or student. This digital-based service instrument product clearly has a technological renewal because it uses the Android application so that in operating the tool can immediately see the test results through a smartphone or tablet. In terms of time, of course, this tool is more effective and efficient in implementing volleyball service skills testing

\section{Conclusions}

Based on the results of the research and discussion above the conclusions and this research is that there is a significant and effective renewal of the existing tools before. The renewal of them, among others, in terms of components of digital-based service test kits is more complex and sophisticated, equipped with quality sensors so that the accuracy of the data is better. In terms of technology the application is equipped with features that are easily understood by every user and is based on Android so that it can be used on smartphones and tablets to see directly the results of tests for each athlete or volleyball player. In terms of time the use is more effective and efficient, and instruments can be used by the age group of 9-30 years, so this tool is really useful for technological advances in the field of sports especially for volleyball.

\section{Acknowledgment}

The researcher would like to thank all those who have provider both moral and material assistance so that this research can be completed. Especially, appreciation goes to families who have supported this research process. Thank the Indonesian Educational Fund Management Institute (LPDP) for fully funding this research through the BUDI-DN scholarship. I would also like to thank Jakarta State University, Bina Darma University and Sriwijaya State Sports School (SONS) for granting permission and assisting the research process. Hopefully the results of this study will contribute to everyone and progress in the achievements of volleyball.

\section{REFERENCES}

[1] Vito, Renò et.al. (2017). A technology platform for automatic high-level tennis game analysis. Computer Vision and Image Understanding. Volume 159, June 2017, Pages 164-175. https://doi.org/10.1016/j.cviu.2017.01.002

[2] Vito, Renò et.al. (2017). A technology platform for automatic high-level tennis game analysis. Computer Vision and Image Understanding. Volume 159, June 2017, Pages 164-175. https://doi.org/10.1016/j.cviu.2017.01.002

[3] M. Manafifard, et.al. (2017) A survey on player tracking in soccer videos. Computer Vision and Image Understanding. Volume 159, June 2017, Pages 19-46. https://doi.org/10.10 16/j.cviu.2017.02.002

[4] Graham Thomas et.al. (2017). Computer vision for sports: Current applications and research topics. Computer Vision and Image Understanding. Volume 159, June 2017, Pages 3-18https://doi.org/10.1016/j.cviu.2017.04.011

[5] Cojocaru, A., \& Cojocaru, M. (2018). Original Article Study on the efficiency of attack in the first division senior male in volleyball JPES ${ }^{\circledR},(5), 1976-1979$. https://doi.org/10.7752/ jpes.2018.s5292

[6] Luminița, a. E., \& valentina, ștefănică. (2017). Comparative study between marketing conducted in two volleyball clubs. Journal of Physical Education \& Sport, 17(5), 22742278.https://doi.org/10.7752/jpes.2017.s5243

[7] Florin, G., \& Bogdan C-Tin, R. (2013). Manifestation of the psychic adaptability skill in performance sport in female volleyball players of C.S. Stiința Bacau. Journal of Physical Education and Sport, 13(3), 381-385. https://doi.org/10.77 52/jpes.2013.03061

[8] Raiola, G. (2014). Teaching method in young female team of volleyball. Journal of Physical Education and Sport, 14(1), 74-78. https://doi.org/10.7752/jpes.2014.01012

[9] Palao, J. M., \& Valadés, D. (2012). Validity of the standing spike test as a monitoring protocol for female volleyball 
players. Biology of sport, 29(4), 281.

[10] Tangkudung, James. Wahyuningtyas Puspitorini. (2012). Sports Coaching._Jakarta: Cerdas Jaya.

[11] Widiastuti. (2015). Sports Tests and Measurement. Jakarta.PT.Raja Grafindo Persada.

[12] Borg, W.R. \& Gall, M.D. Gall. (2007). Educational Research: An Introduction, Eighth Edition. New York: Longman

[13] Sugiyono. (2012).Metode Research Methods Quantitative, Qualitative, and R\&D Approaches. Bandung: ALFABETA

[14] Suharsimi, Arikunto. (2010). Research procedure. Jakarta: Rineka Cipta

[15] Palao, J. M., \& Valades, D. (2009). Testing protocol for monitoring spike and serve speed in volleyball. Strength \& Conditioning Journal, 31(6), 47-51.
[16] Kim and Bomna Ko , (20016). Developing Elementary Content Knowledge in Physical Education Teacher Education. International Journal of Human Movement and Sports Sciences 4(2): 13-19, $2016 \mathrm{http}: / / w w w . h r p u b . o r g$ DOI: $10.13189 /$ saj.2016.040201

[17] Dwi, Gian.O (2015).Development of android-based learning media in the form of digital pocket books for basic competency accounting subjects makes an overview of the service company accounting cycle in class XI MAN 1 Yogyakarta 2014/2015 academic year" Thesis. Yogyakarta State University.

[18] Robert L. Baker dan Richard E. Schutz. (1972). Instructional Product Research (New York: D. Van Nostrand Company.

[19] Satyaputra dan Aritonang. (2014). Beginning Android Programming with ADT Budle. Jakarta: Elex Media Komputindo 